\title{
Gypsum composites, improved by applying basalt dust
}

\author{
Victoria Petropavlovskaya ${ }^{1}$, Aleksandr Buryanov $^{2}$, Tatiana Novichenkova ${ }^{1}$ and Kirill \\ Petropavlovskii ${ }^{*}$ \\ ${ }^{1}$ Tver State Technical University, Af. Nikitin 22, 170026, Tver, Russia \\ ${ }^{2}$ Moscow State University of Civil Engineering, Yaroslavskoe shosse, 26, Moscow, 129337, Russia
}

\begin{abstract}
The paper shows the results of studies of gypsum dispersed systems with the addition of waste production of basalt. Introduction basalt dust allows the physical and mechanical properties of the modified gypsum material. The effect of additives on the strength, density and water absorption of gypsum dispersions hydration hardening.
\end{abstract}

\section{Introduction}

Material consumption is the ratio of the cost of the resources expended in cost price. The lower this ratio, the more efficient production. Saving resources contributes to the growth of production.

Production of building materials is the most raw material intensive part of the construction industry. The cost of materials account for more than half the cost of the finished product. The use of mineral industry wastes is the most effective way to reduce the consumption of materials art. Currently there is growing interest in the world toward the use of basalt fibers. This interest has several reasons: basalt fibers have low thermal conductivity, a large range of operating temperature, chemical and biological stability, ecological safety. Basalt fiber demand in many industries, for example, in mechanical engineering, shipbuilding, energy, aviation [1-7].

However, the productions of basalt fibers large amounts of particulate mineral waste, this basalt dust.

In this paper, the possibility of using pulverized waste as an additive to gypsum composites. The use of waste in the industry will increase the efficiency of production of basalt fiber, by saving resources (waste will have its use value). Also, the waste will provide the construction industry gypsum materials of high quality at an affordable cost.

\section{Materials and methods}

There are several different ways of reinforcement to increase the mechanical properties of materials and gypsum products. These processes are reflected in the work of many scientists [7-16].

\footnotetext{
* Corresponding author: raikiri@inbox.ru
} 
In this paper we investigated the possibility of producing a modified gypsum composition of a reinforcing component in the form of pulverized waste from the production of basalt fibers - basalt dust (Figure 1).

As a starting material, was used gypsum binder - high-strength gypsum G-16 Samara gypsum combine. As an additive used pulverized waste basalt fiber production (Tver region.). Waste is not utilized at present in production.

Chemical and phase composition of basalt dust are given below (Table 1, 2).

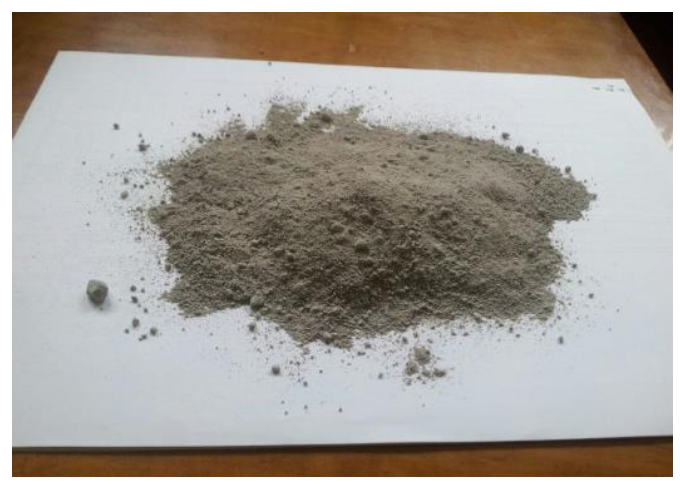

Fig. 1. Basalt dust.

Table 1. The chemical composition of the dust.

\begin{tabular}{|c|c|c|c|c|}
\hline \multirow{2}{*}{ Oxide } & \multicolumn{5}{|c|}{ Content } \\
\cline { 2 - 5 } & 1 point & 2 point & 3 point & Mean \\
\hline $\mathrm{CO}_{2}$ & 4.55 & 4.93 & 4.41 & 4.63 \\
\hline $\mathrm{Na}_{2} \mathrm{O}$ & 4.15 & 3.62 & 3.70 & 3.82 \\
\hline $\mathrm{MgO}$ & 8.95 & 8.88 & 8.78 & 8.87 \\
\hline $\mathrm{Al}_{2} \mathrm{O}_{3}$ & 2.69 & 3.02 & 2.78 & 2.83 \\
\hline $\mathrm{SiO}_{2}$ & 67.77 & 68.02 & 69.20 & 68.33 \\
\hline $\mathrm{SO}_{3}$ & 1.15 & 1.13 & 0.98 & 1.09 \\
\hline $\mathrm{Cl}_{2} \mathrm{O}$ & 1.56 & 1.05 & 1.49 & 1.37 \\
\hline $\mathrm{K}_{2} \mathrm{O}$ & 1.78 & 1.67 & 1.52 & 1.66 \\
\hline $\mathrm{CaO}_{2}$ & 3.59 & 3.97 & 3.91 & 3.82 \\
\hline $\mathrm{Fe}_{2} \mathrm{O}_{3}$ & 3.81 & 3.71 & 3.23 & 3.58 \\
\hline
\end{tabular}

Table 2. Phase composition of dust.

\begin{tabular}{|c|c|c|c|c|}
\hline Specimen & Calcite & Dolomite & Quartz & $\mathrm{NaCl}$ \\
\hline Waste & 2.9 & 19.0 & 4.9 & 13.2 \\
\hline
\end{tabular}

To study the properties of modified gypsum stone were made standard samples 20x20x20 and 40x40x160. After curing were tested in the standard time in accordance with the requirements of GOST 23789-79 "Binding gypsum. Test Methods.

The distribution of dust particle size was determined by laser diffraction according to ISO 13320-1:2009 "Particle size analysis. Laser diffraction methods" on the laser microprobe particle size« Analysette 22 ".

Differential and integral distribution of the particles in the mixture of gypsum binder and additives dust optimum granulometric composition was obtained by using the software package "computer program select the optimum granulometric composition the aggregate 
of the construction of the composite material" (Figure 2). The water content in the experiments varied from 0.36 to 0.375 , the scanning step was 0.05 , the dust content was varied from 6 to $12 \%$ in increments of two.

\section{Results. The study of basalt dust}

The average size of the dust particles of basalt $-\mathrm{d} 50=24.866$ microns. The maximum particle size $-\mathrm{d} 99=111.743$ microns. Particles less than 2 microns $=9.66 \%$ by weight. Research has established the presence of $60 \%$ amorphous component (Figure 3). This is confirmed by an increase in the background intensity at $\mathrm{d}=2.5-3.4 \AA$.

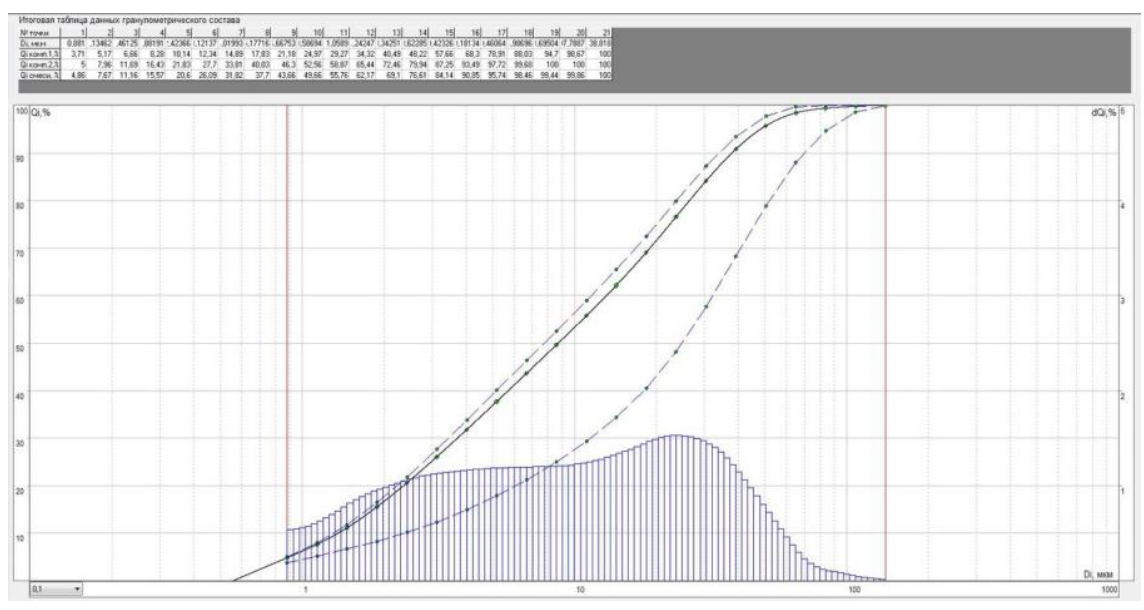

Fig. 2. Differential and integral particle size distribution in the mixture of a modified gypsum.

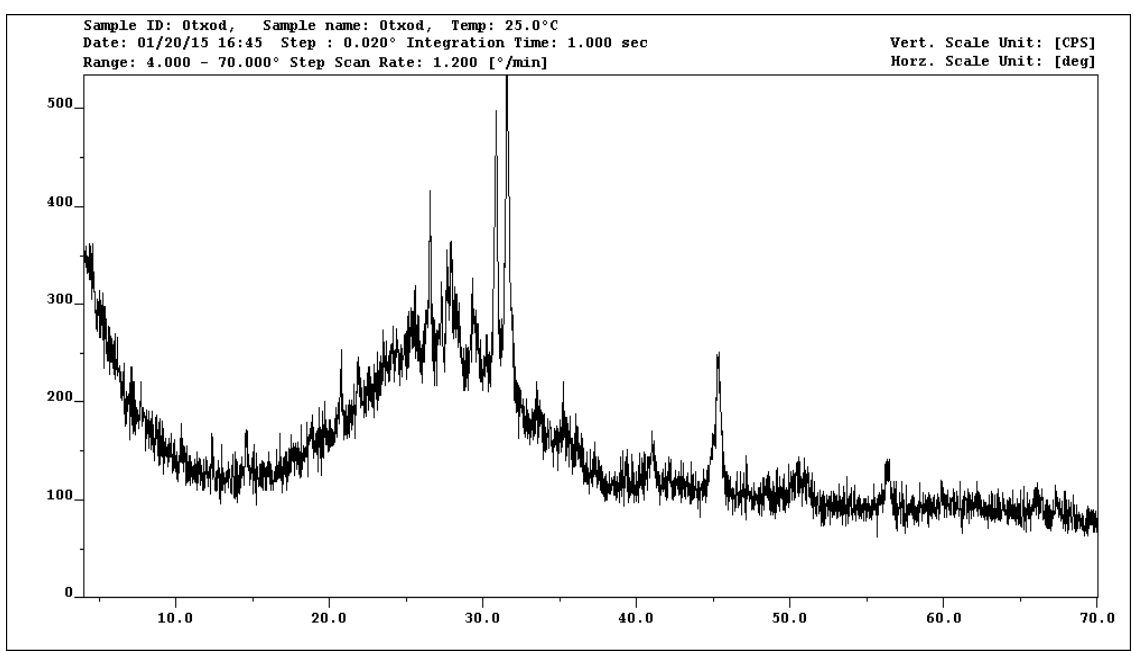

Fig. 3. The diffraction pattern of the sample dust.

\section{Results. Study of modified composites}

The greatest value of the bending strength of gypsum at a content of $10 \%$ basalt dust and numerically is $7.96 \mathrm{MPa}$. The average density of gypsum with $1687 \mathrm{~kg} / \mathrm{m} 3$ (Figure 4). Bending strength increased with the introduction of dust by $10 \%$. This is due to the 
participation of basalt dust in physico-chemical transformations hardening gypsum. This can be attributed to the chemical homogeneity of the substances involved in the process of structure formation.

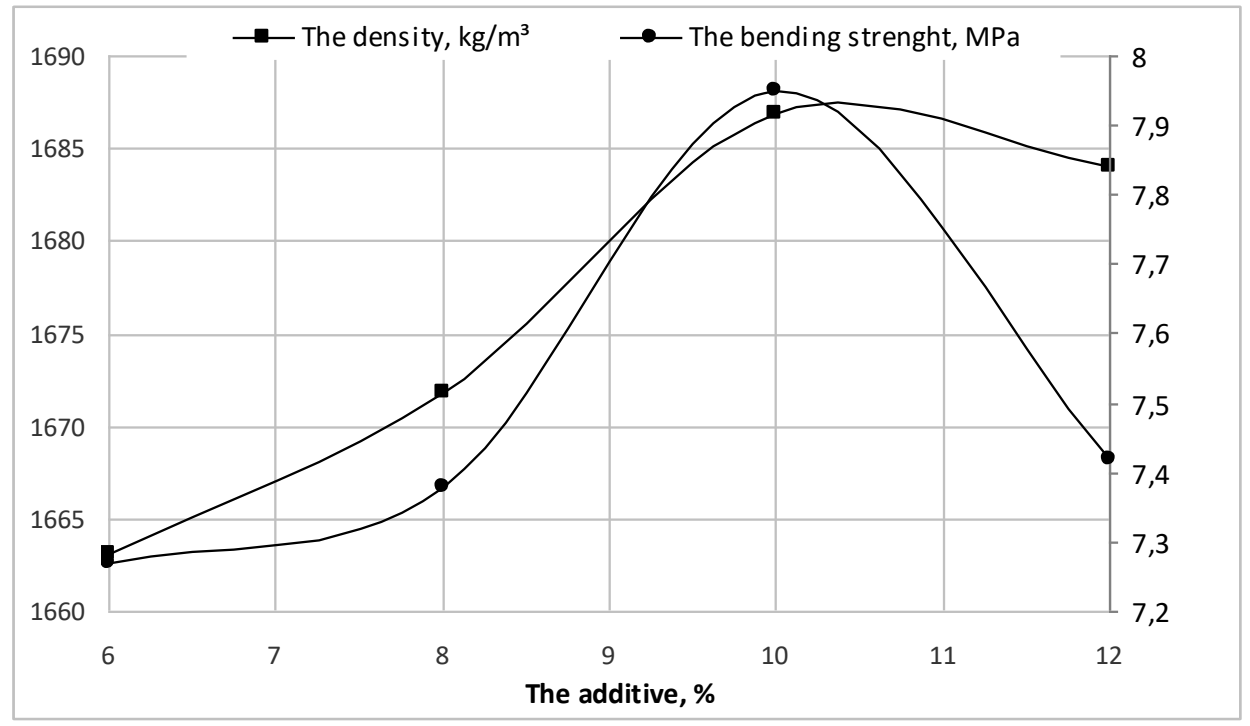

Fig. 4. Effect of additives on the strength and the density.

Effect of basalt dust on the properties of gypsum largely reflected in the compressive strength (Figure 5). Compressive strength increases almost 2-fold compared to samples without additive. The optimum amount of additive $-10 \%$.

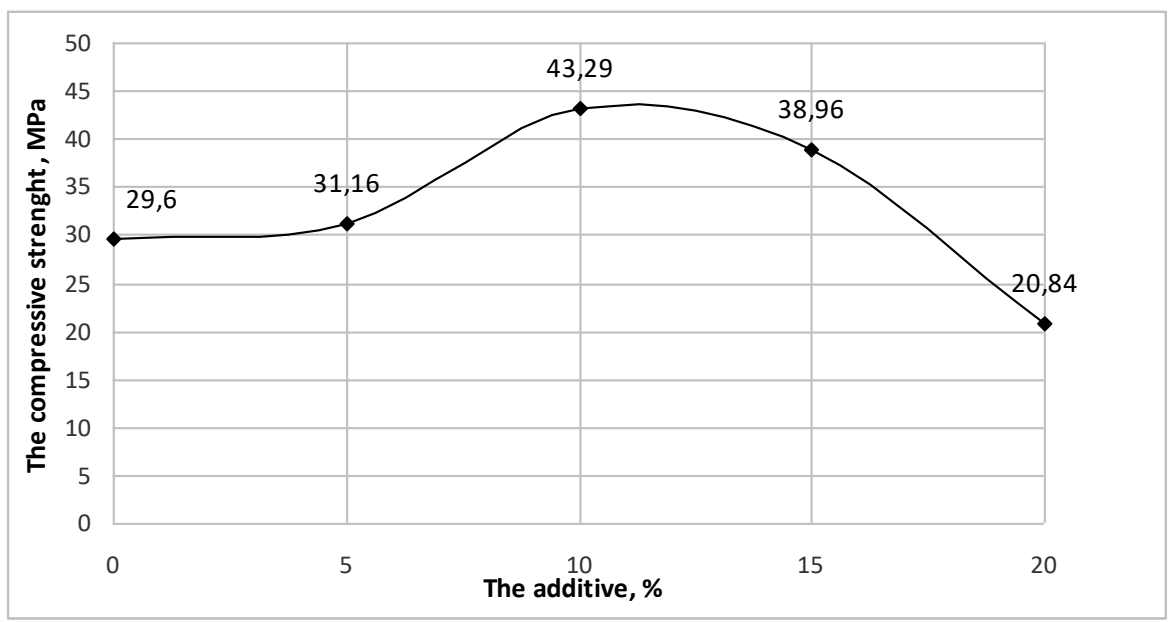

Fig. 5. Effect of additives on the compressive strength.

The optimum water content corresponding to the value of 0.365 . The smooth surface of the basalt particles contributes workability, reduce water demand and porosity, and hence improve durability (Figure 6, 7).

According to the results of experiments we can conclude that the physical and mechanical properties of gypsum composites are determined by basalt dust and waste content and water content. The greatest strength of $58 \mathrm{MPa}$ at a water content of 0.365 (Figure 7), while the average density of the samples is about $1647 \mathrm{~kg} / \mathrm{m} 3$ (Figure 8). 


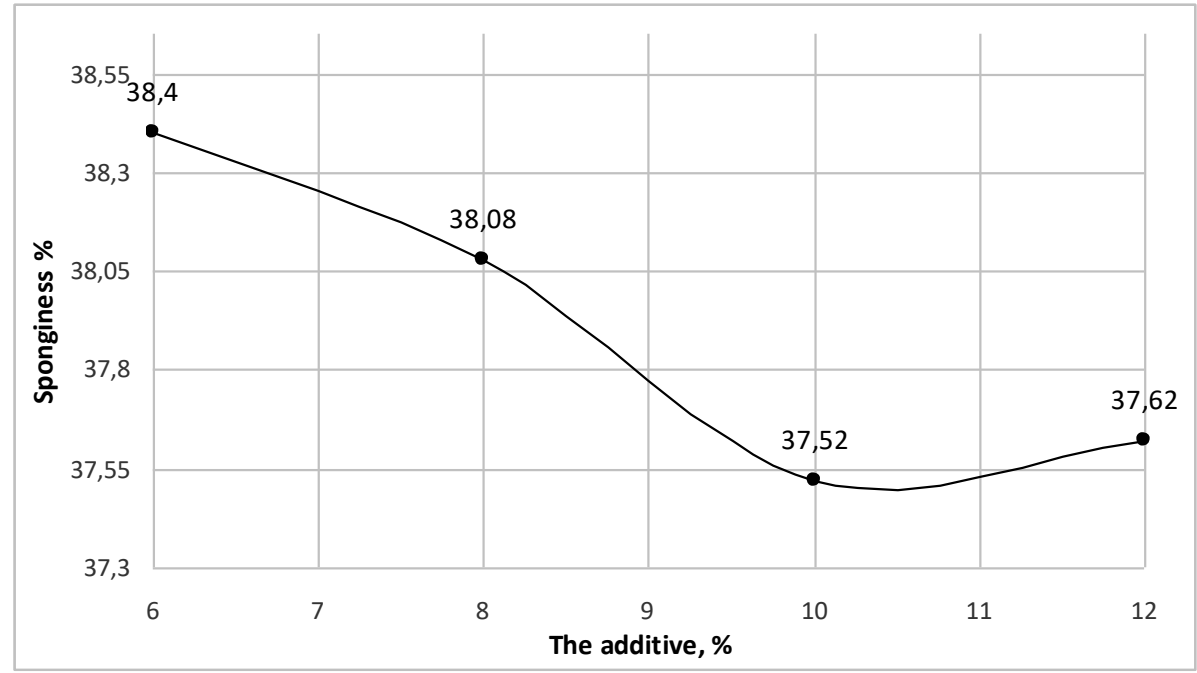

Fig. 6. Effect of additives on the sponginess.

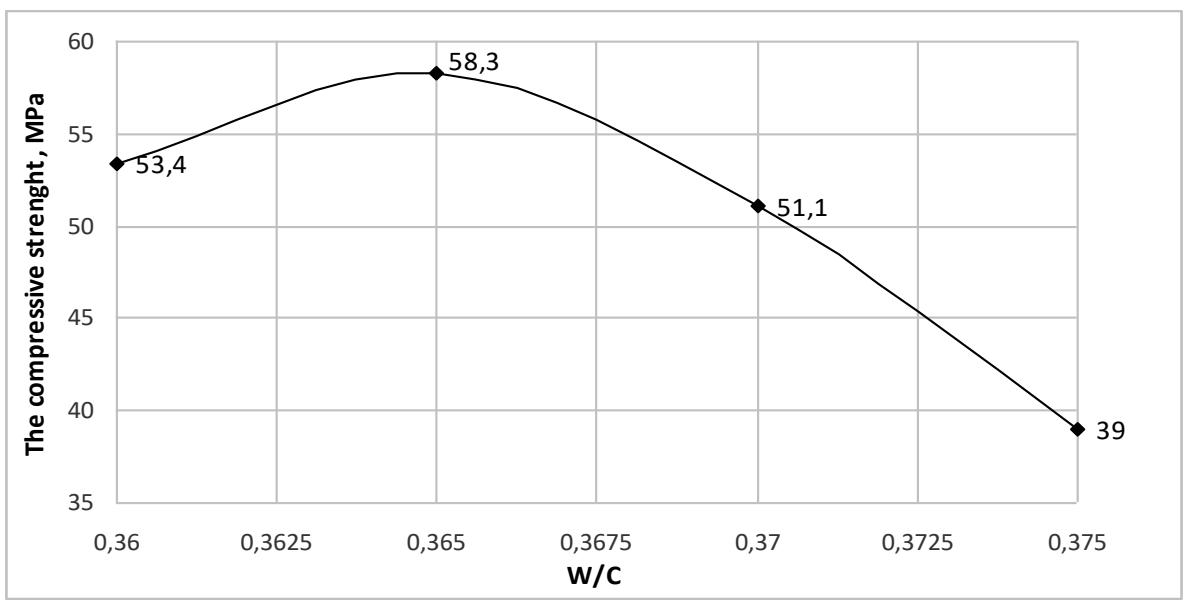

Fig. 4. Influence of water on the compressive strength of the modified gypsum.

Low water content does not provide moldability. With increasing content of more than 0,365 is present in the system "excess water", it does not take part in the hydration process increases the porosity of the product, reducing its density. 


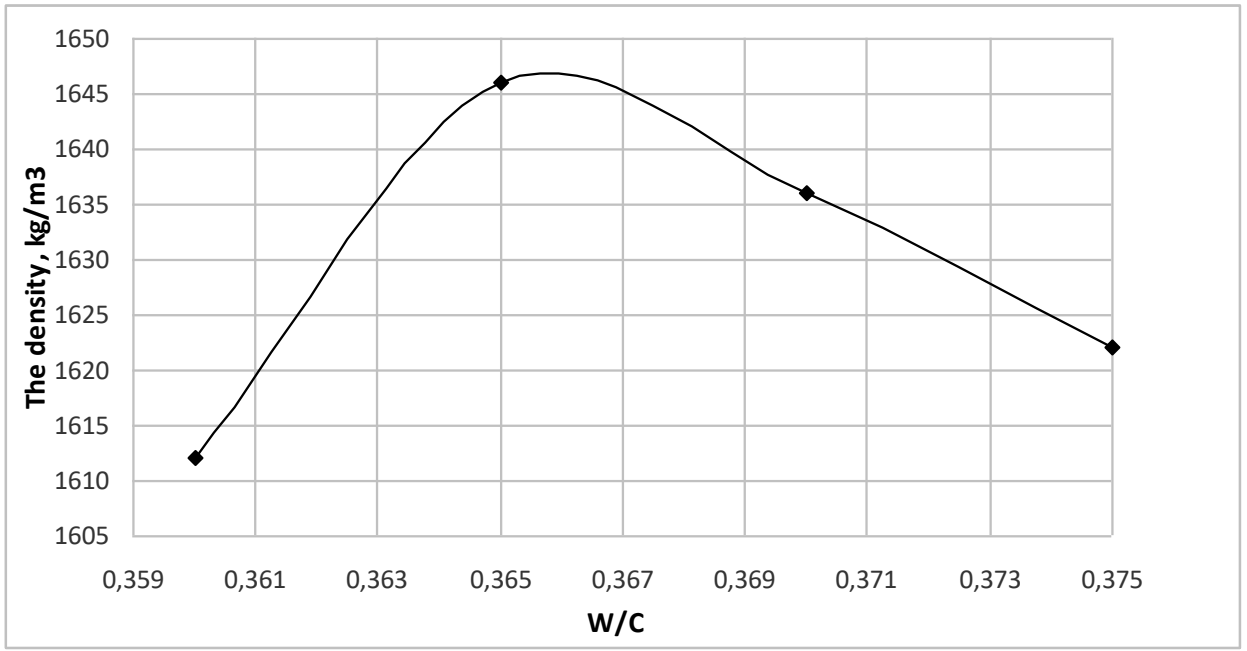

Fig. 8. Effect of the water content by the density modified gypsum.

Also, $\mathrm{pH}$ of the solutions were determined basalt dust, gypsum and gypsum mixture with $10 \%$ of the dust, the results shown in Table 3

Table 3. $\mathrm{pH}$ solute.

\begin{tabular}{|c|c|c|c|}
\hline Solute & Gypsum & Basalt dust & Gypsum and 10 \% basalt dust \\
\hline $\mathrm{pH}$ & 6,95 & 6,22 & 6,53 \\
\hline
\end{tabular}

Change alkalinity affects the formation of the structure of a modified gypsum. Contained in basalt alkaline components $(\mathrm{Na}+, \mathrm{K}+)$ increases the alkalinity of the medium, thereby activating the process of structure formation in the system, since the sulfates deposited more fully in alkaline environment.

\section{Conclusions}

The strength of composites reinforced with basalt dust, due to give a more dense packing of the particles, this contributes optimally matched grain composition, as well as the chemical affinity of gypsum and basalt. Improving the efficiency of the composites, primarily due to the optimization of the internal structure.

The lead researches it has been established the possibility of effective gypsum compositions with improved performance properties by introducing a modifying mineral additive in the form of waste dust extraction from basalt fiber production. This will allow for the construction industry gypsum of high quality materials at a low cost as well as improve the efficiency of production of basalt fiber, as a result of the processing of their waste in a real product that has cost.

\section{References}

1. H.A. Hezhev, Yu.V. Pukharenko, Vestnik grazhdanskikh inzhenerov 2(37), 152-156 (2013)

2. D. Mognonov, Stroitel'nye Materialy 10, 28-30 (2012)

3. V.B. Babayev, V.V. Strokova, V.V. Nelyubova, Vestnik Belgorodskogo gosudarstvennogo universiteta imeni V. G. Shukhova, BGTU 4, 58-61 (2012) 
4. V. Lesovik, G. Elias, Belgorod State Technological University, Shukhov: BGTU, 109193 (2010)

5. V. P. Kuzmina, Nanotechnology Research online journal 2, 59-64 (2011)

6. M.S. Osnos, S.P. Osnos, Composite World 5(26), 36-39 (2009)

7. V.V. Belov, A.F. Bur'yanov, G.I. Yakovlev, Modification of structure and properties of construction composites on the basis of calcium sulfate: monograph (De Nova, Moscow, 2012)

8. V.B. Petropavlovskaya, T.B. Novichenkova, A.F. Buryanov, J.-B. Fisher, Stroitel'nye Materialy 7, 19 - 21 (2014)

9. D.G. Sagdatullin, N.N. Morozova, V.G. Khozin, Proceedings of the Kazan State Architectural University 2(12), 263-268 (2009)

10. A. Ferronsky, Gypsum materials and products (production and use) (DIA, Moscow, 2004)

11. D.O. Bondarenko, V.V. Strokova, A.M. Rykunov, V.V. Nelyubova, Materials of the International scientific and practical conference devoted to FGBOU VPO'S 95 anniversary of "GGNTU of the academician M. D. Millionshchikov", 134-139 (2015)

12. Yu.V. Tokarev, E.O. Ginchitskii, G.I. Yakovlev, A.F. Bur'yanov, Stroitel'nye Materialy 6, 84-87 (2015)

13. R.Z. Rakhim, M.I. Khaliullin, A.R. Gayfullin, Stroitel'nye Materialy 7, 13-15 (2012)

14. V.V. Strokova, A.V. Cherevatova, I.V. Zhernovsky, E.V. Wojtowicz, Building Materials, 7 (2012)

15. M.S. Garkavi, A.Y. Panferova, S.A. Nekrasov, K.A. Mikhailov, Dry mixes 2, 38-40 (2013)

16. I.S. Maeva, G.I. Yakovlev, G.N. Pervushin, A.F. Buryanov, A.P. Pustovgar, Building Materials 6, 45 (2009) 